\title{
Glucose and Glucagon Do Stimulate Somatostatin Release from Isolated Pancreatic Islets
}

Dear Sir,

We would like to draw your attention to contradictory statements in relation to our work (references 1 and 2 in this letter correspond to references 12 and 11 in the review by $\mathrm{K}$. Hermansen) reported in a recent review published in Diabetologia [3]. Indeed, Dr. Hermansen quoted our results correctly by stating that neurotensin "inhibited D cell secretion during stimulation with very high glucose concentration $(23 \mathrm{mmol} / \mathrm{l})$ ", and by referring to our work [2] among other references when he wrote that "glucagon has consistently been reported to stimulate pancreatic somatostatin secretion." However, quoting the same references [1, 2], Dr. Hermansen contended that "since the D cells (of our preparation) of isolated islets were unresponsive to variations in glucose from 3 to $23 \mathrm{mmol} / \mathrm{l}$, and to the addition of $2 \mu \mathrm{g} / \mathrm{ml}$ glucagon, the results must be viewed cautiously".

This is inconstistent not only with our data $[1,2]$ but also with what Dr. Hermansen wrote in his review. Therefore, the contention that "the results must be viewed cautiously" is not warranted and is based on misinterpretation of the data (Fig. 1).

J. Dolais-Kitabgi, P. Kitabgi and P. Freychet

\section{References}

1. Dolais-Kitabgi J, Kitabgi P, Brazeau P, Freychet P (1979) Effect of neurotensin on insulin, glucagon, and somatostatin release from isolated pancreatic islets. Endocrinology 105: 256-260

2. Dolais-Kitabgi J, Freychet P (1979) Neurotensin inhibits glucose but not glucagon-induced insulin and somatostatin release in isolated islets. Diabete Metab 5: 275-277

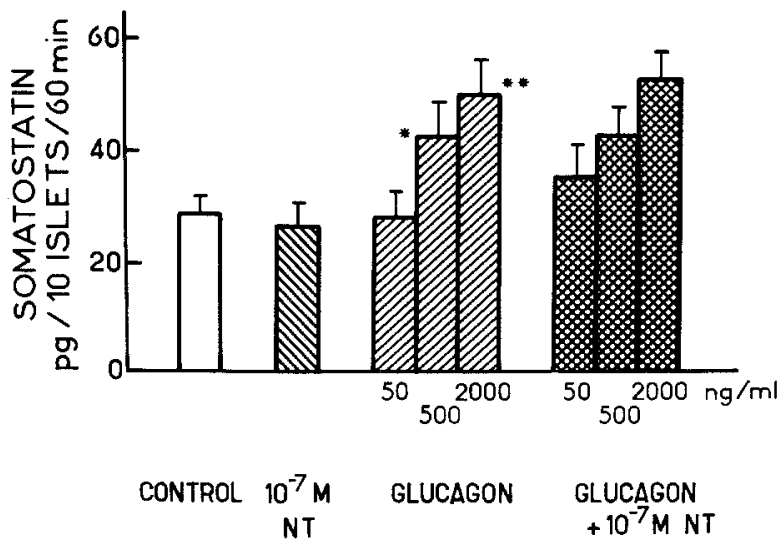

Fig. 1. Effect of glucagon and glucagon plus neurotensin on somatostatin release. Pancreatic islets were incubated for $60 \mathrm{~min}$ in the presence of $12 \mathrm{mmol} / \mathrm{l}$ glucose alone (control $\square$ ) or in the presence of $12 \mathrm{mmol} / \mathrm{l}$ glucose plus neurotensin (NT $\mathbb{N}$ ) or glucagon at varying concentrations or both. Values are means of 18-26 individual observations obtained from eight separate experiments. ${ }^{*} p<0.05$ versus control; ${ }^{* *} p<0.005$ versus control

3. Hermansen K (1980) Secretion of somatostatin from the normal and diabetic pancreas: Studies in vitro, Diabetologia 19: 492-504

Dr. J. Dolais-Kitabgi

INSERM U 145

Faculté de Médecine

F-06034 Nice Cédex, France

\section{Visual Flicker Discrimination in Diabetes}

\begin{abstract}
Dear Sir,
One simple means of quantitatively estimating the effect of diabetic complications on visual function is the evaluation of visual acuity. The intent of our efforts has been to develop a sensitive auxilliary method to evaluate another aspect of diabetic vision. We have completed a preliminary study in which measures of visual flicker discrimination were employed. Because diabetics have poorer colour vision than the general population and the deterioration tends to affect the ability to discriminate between blue and other colours $[1,2]$, we developed an optic stimulator which provides either primarily a blue or a red stimulus. Our objective was to determine whether flicker discrimination using blue light would
\end{abstract}

be a more sensitive indicator of impairment than would that with red light. The visual test field of our apparatus consisted of a background area $\left(8^{\circ}\right.$ by $\left.8^{\circ}\right)$ with a centrally embedded red $(660 \mathrm{~nm})$ light-emitting diode which subtended $3 / 4^{\circ}$. A white light source produced illumination for the background and either a red (approximately $660 \mathrm{~nm}$ ) or blue (approximately $480 \mathrm{~nm}$ ) colour could be imparted to it by placement of filters between the eye and the background. Our method for determining the critical flicker fusion frequency (i. e. that frequency at which a flickering light will just appear solid) has been described previously [3]. Here, however, the procedure was done with a blue background as well as with a red background. 


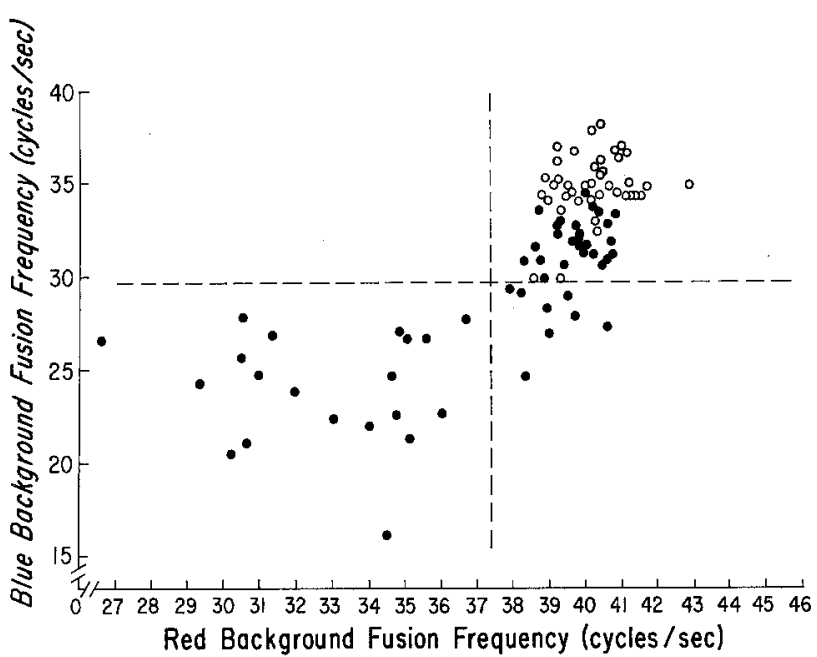

Fig. 1. Relationship between blue and red flicker discrimination values for the control $(\circ, n=40)$ and diabetic $(\bullet, n=54)$ eyes tested. A flicker fusion value lower than three standard deviations from the mean of the control group was defined as abnormal. A value below horizontal dashed line indicates abnormal flicker discrimination with blue background. A value to the left of vertical dashed line indicates abnormal flicker discrimination with red background

Table 1. Comparison between blue and red background flicker discrimination in diabetic eyes tested

\begin{tabular}{llll}
\hline $\begin{array}{l}\text { Classification of } \\
\text { diabetic group }\end{array}$ & $\begin{array}{l}\text { No. of } \\
\text { eyes tested }\end{array}$ & $\begin{array}{l}\text { \% abnormal } \\
\text { red CFF }\end{array}$ & $\begin{array}{l}\% \text { abnormal } \\
\text { blue CFF }\end{array}$ \\
\hline $\begin{array}{l}\text { Normal findings } \\
\text { Background }\end{array}$ & 26 & $27(7 / 26)$ & $35(9 / 26)$ \\
$\quad$ retinopathy only & 15 & $33(5 / 15)$ & $60(9 / 15)$ \\
Cataract only & 6 & $33(2 / 6)$ & $67(4 / 6)$ \\
Complex & 7 & $85(6 / 7)$ & $85(6 / 7)$ \\
Total & 54 & $37(20 / 54)$ & $52(28 / 54)$ \\
\hline
\end{tabular}

$\mathrm{CFF}=$ critical fusion frequency

Control values were obtained from 20 non-diabetic patients (40 eyes). Twenty-eight diabetic patients ( 54 eyes) attending the diabetic clinic were studied. All subjects were less than 61 years old, with the mean age of the control group ( $36 \pm 10$ years) less than that of the diabetic group ( $47 \pm 13$ years). About $80 \%$ of the patients were taking insulin. Mid-morning post-prandial plasma glucose values were available for 23 patients with mean \pm SD of
$18.0 \pm 6.5 \mathrm{mmol} / \mathrm{l}$. Glycosylated haemoglobin values were available for 10 patients with a range of 7.3 to $13.4 \% \mathrm{~A}_{1}$ and mean \pm SD of $10.2 \pm 2.1 \%$. From the ophthalmological findings, corrected visual acuity ranged from $20 / 20$ to $20 / 80$ with average acuity of better than $20 / 30$. A comparison of the diabetic and control eyes studied is shown in the scattergram (Fig. 1). Eight of the eyes studied showed an abnormal flicker discrimination with the blue background condition but not with the red background condition. For the most part, if an abnormality existed it involved both colours. A classification scheme with four groups was established as follows: 1) normal (a group of 26 eyes with no abnormal findings by fundoscopy); 2) background retinopathy (a group of 15 eyes with evidence of mild vascular changes with or without hard or soft exudates or oedema); 3) cataract (a group of six eyes with evidence of cataract within the lens); and 4) complex lesions (a group of seven eyes with cataract plus background changes, or proliferative retinopathy, or laser treatment). As shown in Table 1, an eye with normal findings by fundoscopy can show abnormal flicker discrimination.

Our preliminary results indicate that measures of flicker discrimination can present evidence of impairment when other findings are normal. The impairment is more often evident when blue light is used. Further study of flicker discrimination using blue light might determine whether 1) loss of the blue response is associated with damage to specific retinal areas as demonstrated by fluorescein angiography and 2) a relationship exists between diabetic regulation and critical fusion frequency changes which occur over a period of months.

Yours sincerely,

M. L. Daley and M. C. Riddle ${ }^{1}$

${ }^{1}$ Dr. Riddle is from the Department of Surgery, University of Oregon Health Sciences Center

\section{References}

1. Kinnear PR, Aspinall PA, Lakowski R (1972) The diabetic eye and colour vision. Trans Ophthal Soc UK 92: 69-78

2. Birch-Cox J (1978) Defective colour vision in diabetic retinopathy before and after laser photocoagulation. Mod Prob Ophthal 19: 326-329

3. Daley ML, Swank RL, Ellison CM (1979) Flicker fusion thresholds in multiple sclerosis. Arch Neurol 36: 292-295

M. L. Daley

Neurosurgical Research

University of Oregon Health Sciences Center

3181 S. W. Sam Jackson Park Road

Portland, Oregon 97201, USA 